\title{
Leaders Address Inequity Through a Framework of International-Mindedness
}

\author{
Carol Van Vooren \\ Delores B. Lindsey \\ California State University San Marcos
}

ABSTRACT: This paper offers school leaders and scholar practitioners twin frameworks of international-mindedness and cultural proficiency as a means to addressing persistent education gaps. International-mindedness is a global perspective framework and cultural proficiency is an equity-focused framework. These complementary frameworks are grounded in the educational policies and practices found in the International Baccalaureate (IB) programs. In an era focused on closing achievement gaps, students from diverse backgrounds have opportunities to engage in topics and dispositions in IB that connect to their prior knowledge and experiences through a new lens and global perspective.

Once viewed as an elitist high school program, the IB is now offered in an increasing number of public schools as a school wide initiative to support the needs of all students, including language learners and students from low socio-economic backgrounds. Teachers and school leaders in IB schools teach human similarities and differences through a local and global perspective to better prepare and engage all students in the knowledge and skills they will need in the changing world of the 21 st century. To realize this expanded goal of access and achievement for all students, school leaders and educators must also understand the complementary conceptual frameworks of cultural proficiency and international-mindedness.

The authors recommend that by aligning the frameworks of international-mindedness and cultural proficiency, students of all demographic groups and their teachers become aware of a wider world, respect and value diversity, understand how the world works, participate both locally and globally, and may be motivated to take action as engaged citizens.

\section{Introduction}

Clearly a desperate need exists to close the achievement gap in our public schools. To fully participate in the educational process, all students must feel they are valued and their families are respected. International-mindedness, a framework within the International Baccalaureate philosophy, is based on context-driven curriculum developed around global themes and respect for multiple perspectives that can be embraced by all learners. In this constructivist approach, international-mindedness takes into consideration humanistic values, shifting demographics, and twenty-first century skills, all issues confronting today's school leaders.

The purpose of this paper is to connect leaders to research and current practices in the frameworks 
of international-mindedness and cultural proficiency through the International Baccalaureate (IB) K-12 schools. Thethreetheoretical constructs of InternationalMindedness, Cultural Proficiency, and International Baccalaureate provide leaders a solid grounding in how to move forward with change initiatives that impact student achievement. When leaders lead believing all educators can educate all learners, educators begin to view all students, including those from culturally diverse backgrounds, as academically capable (Lindsey, Robins, \& Terrell, 2009).

International-mindedness in the IB, like cultural proficiency, begins with the knowledge of one's self and expands to inclusion of and by all students. From this foundation of inclusion, educators and students are taught to learn and respect the family heritage, culture, and backgrounds of themselves and each other in their classes, their school and community, and to a universal application. They learn to listen to other perspectives with an open mind. This global/local-or "glocal"perspective is modeled by the teacher and the school leaders and may be evidenced by the mission statement of the school. The concept of international-mindedness gives promise to narrowing the achievement gap for students in schools that do not have access to world traveling experiences and provides a framework for school leaders to reduce the access and equity gap. With a framework of international-mindedness, students from diverse backgrounds have the opportunity to engage in topics and dispositions that connect to their prior knowledge from their family upbringing or experiences in their country of origin.

From our research and experiences as teachers, school principals, and university professors, international-mindedness in the IB, linked with cultural proficiency, actively prepares students for the 21st century in a global society.

\section{Connecting Local and International Educational Issues}

At a recent International Baccalaureate Conference of the Americas, one of us joined a panel of university professors in discussing the role of internationalmindedness in educator training. As panel members spoke, the tension from the various perspectives on the topic was evident. Even from experts, a wide variety of definitions and implementation of internationalmindedness existed among the panel of educators at all levels. For some educators the term internationalmindedness is the educational experiences of expatriots' children studying in a foreign country, while for others the view of international-mindedness is of foreign exchange students living in family homes and attending schools in the United States. These opportunities certainly exist for an elite group of students, but we believe that international-mindedness serves all students in their local communities in preparation for life in a global society. So, our questions become, what teacher dispositions and skills are necessary to implement an international-mindedness philosophy and framework in schools where students have not been served well or need to be served differently, and why is international-mindedness an important pedagogy and curriculum for underserved students?

\section{Emergence of International Educational Pedagogy in American Public Schools}

The 21st century is a very different world from the world in which international schooling was first launched. Schools around the world have long studied international issues in literature, history, geography, and world language classes. Over time, the curriculum in U.S. schools has correlated with major social, political, and moral shifts in thinking (Ravitch, 2010). Often, the curriculum is defined and implemented by those in power and the best thinking of the time (Young, 2009). For example, California recently passed the Fair, Accurate, Inclusive, and Respectful Education Act (SB 48), which adds sexual orientation and gender identity to the state's existing protections in school activities, instruction, and instructional activities. This act has opened the doors to include the Harvey Milk story of gay activism and other key figures in California history books, a part of history that is new to the textbooks of our time (Pierce, 2011). As society has changed, so have the policies and decisions that affect schools and their communities.

The beginnings of global thinking in schools were influenced by Europe in the 1940s at the International School of Geneva, whose director, Marie-Thérèse Maurette, brought international-mindedness to her 
school. She included learning a second language and service learning for the international students to engage in their new community. According to former IBO Director General George Walker (2011), Marie-Thérèse Maurette began the concept of the IB diploma program in her 1948 paper for the United Nations Educational, Scientific and Cultural Organization (UNESCO) called "Ways for educating for peace: Do they exist?" This report defined how to educate students to "become members of the human race as a whole in addition to being citizens of separate nations" (Walker, 2009, para. 6). Maurette's goal was to enrich her students' shared experiences among their different cultures together with the art, literature, and home country traditions. One of the students from the original International School of Geneva, Fredrika Tuttle Blair, wrote to the New York Times in support of an international school launch in New York based on her experiences of joining a community of students from around the world and facing the reality of World War II:

In teaching us to judge one another as individuals, the school risked shocking us when we returned to a world in which prejudice and national antagonisms were fostered. But it is not a bad thing to be shocked. You cannot accept the unjust and arbitrary as inevitable if you have known a place where justice and reason work. (Blair, 1947, para. 30)

By the 1960s, fifty international schools were located around the world and they ushered in a framework of international educational pedagogy. In 1962 the term International Baccalaureate emerged and in 1963 the high school diploma program exams began (Walker, 2011). In the 1970s, the American civil rights movement and beginning concepts of social equality were present. By the 1980s and ' 90 s, the formation of global systems, international influence, and technological innovation changed the face of communication. By the turn of the century, civic responsibility included social justice work, and students were widely participating in service learning in their communities and beyond (Kielburger, Kielburger, \& Page, 2010). Former IB Director General Gerard Renaud said, "This international humanism will be the only way that will lead to the progressive disappearance of prejudices and mistaken ideas about foreigners, prejudices which underlie intolerance and isolation" (Walker, 2011, p. 7).

The concept of international-mindedness is at the forefront of the IB mission statement:

The International Baccalaureate aims to develop inquiring, knowledgeable and caring young people who help to create a better and more peaceful world through intercultural understanding and respect.

To this end the organization works with schools, governments and international organizations to develop challenging programmes of international education and rigorous assessment.

These programmes encourage students across the world to become active, compassionate and lifelong learners who understand that other people, with their differences, can also be right. (International Baccalaureate Organization, 2011)

Over the last 10 years, the International Baccalaureate (IB) at the elementary and middle years' levels, along with other international educational programs such as the International Schools Association and Education for Peace, has greatly expanded. International-mindedness now has open access to many more students at public IB schools, which represents a shift from solely private school implementation. More than $50 \%$ of the 3,900 worldwide IB schools are state operated and more than $75 \%$ of the California IB schools are publicly funded (International Baccalaureate Organization, 2012). With the expansion of IB to public schools in school-wide programs, this rigorous, internationally minded curriculum is available to all student demographics, bringing the potential to reduce the achievement gap for students enrolled in those schools.

\section{Changes in Our World}

Several factors in our world have increased 
the need to develop the skills of internationalmindedness for students in local schools. First of all, student demographics have become more diverse in most urban, public U.S. schools. In California, 51\% of the students enrolled in K-12 schools are Latino, $27 \%$ are White, and the remaining 22\% includes students from Asian ethnicities, Filipinos, African Americans, Native Americans, Pacific Islanders, and students of two or more races (California Department of Education, 2011). This diversity gives teachers the opportunity to investigate, share, and celebrate the richness of different cultures and student experiences through international-mindedness pedagogy and curriculum. English learners, including those from low socioeconomic backgrounds, have recent experiences in their home countries and can contribute to lessons and concepts surrounding global themes.

New technologies such as social media and online learning have also influenced international-mindedness in the classroom. Patterns of human experiences are easily located on the Internet and are shared quickly among technology-savvy students. Students can study online information such as the Gapminder fact-based view of the world on health and wealth by Hans Rosling (BBC Four, 2010), and a British newspaper's online Arab protests moving dateline path linked to photos of events that are changing the Arab world (Blight, Pulham, \& Torpey, 2011).

Another factor influencing the need to teach international-mindedness is the expanding global marketplace. American media is barraged with global themes. The motto, "Let's make the world a smarter place" is the core of IBM's advertising, and Visa focused on the "Go World" campaign in the last Olympics. CocaCola employed professional basketball players LeBron James (USA) and Yao Ming (China) to grab a Coke together.Global thinking and international-mindedness have entered the mass market as popular themes. Marketing experts know that the next generation will be involved in some way in a global world, and they are positioning to appeal to that audience.

Economically, the world is shrinking as borders become transparent though the use of online workforces, cheaper labor for outsourced work, and global money exchange. The interrelationship of economic successes and failures of large and small countries has a ripple effect in the worldwide economy.

Finally, student knowledge and skills in international-mindedness has the potential to raise consciousness about the environment and spread peace in the world.

Changing demographics, the rapid expansion of technology, the globalization of mass media, the expanded world economy, and the potential to take care of the planet and others drives the concept of international-mindedness for all students. Teachers and school leaders have the potential to open student thinking to human similarities and differences on a local and global perspective to better prepare and engage all students in the knowledge and skills they will need in the changing world of the 21st century.

\section{Era of Accountability and Achievement Gaps}

The urgency to reach all students increases as the numbers of English learners, low socioeconomic students, and immigrant children grow in American public schools. Even though No Child Left Behind (NCLB) (2002) offered hope for underserved demographics, data indicate that achievement gaps between demographic groups continue to grow (Donald, 2012). The acknowledged achievement gap reported by the National Assessment of Educational Progress (NAEP) indicates that scores in 2009 between Hispanic and White students at grades 4 and 8 in mathematics and reading showed a gap between 21 and 26 points on the NAEP scaled score (Institution of Education Sciences, 2011). The gap in student learning indicates many students are at risk of exclusion from the benefits and opportunities offered to the well educated. This continuing gap highlights the need for teacher training and appropriate curriculum to meet the needs of the increasing diversity in schools.

Diversity should be embraced as an asset rather viewed as a deficient (Lindsey, Jungwirth, Pahl, \& Lindsey, 2009). In schools that embrace internationalmindedness, English-learner families offer experiences to share and foster diverse cultural presence in the classroom. Funds of Knowledge (Moll, 1992) posits a view that the parents and multicultural communities possess important historically developed and accumulated knowledge, abilities, strategies, ideals, practices, and cultural events that are regarded as 
important to family well-being. When these skills are known and valued by the teacher and embedded in the curriculum, international-mindedness and culturally proficient instruction have the potential to benefit all children. Children who are not stereotyped but valued for their individuality are more successful academically in school than those who may feel stereotyped (Steele, 2010). Recently, Django Paris, in his article calling for changing practices to sustain cultural pedagogy, wrote the following:

I, like countless teachers and universitybased researchers, have been inspired by what it means to make teaching and learning relevant and responsive to the languages, literacies, and cultural practices of students across categories of difference and (in) equality. (Paris, 2012, p. 94)

For students in public schools, learning about the strengths represented by the cultures of different students in their classes is powerful in creating a sense of community. Twenty years ago, Roger Peel, former general director of the International Baccalaureate Organization, stated, "We ask students to relate first to their own national identity and then the identity and the traditions of others. The student is aware of a wider world, respects and values diversity, understands how the world works, participates from local to global, and is willing to take action" (Walker, 2011, p. 7). Alchin (2008), the science chair of Sevenoaks IB World School in the U.K., reminds us that "examining one's culture is open to all students" (p. 19).

\section{A Framework for International-Mindedness}

A description at the IB website states that their programs are unique because "we encourage international-mindedness in IB students. To do this, we believe that students must first develop an understanding of their own culture and national identity" (International Baccalaureate Organization, 2012, para. 3). Students, teachers, and leaders experiencing an IB curriculum must understand and appreciate their own cultures and personal histories while remaining open to the perspectives, values, and traditions of other individuals and communities. Internationally minded learners are accustomed to seeking and evaluating a range of viewpoints and are willing to grow from the experience.

In the International Baccalaureate, self awareness begins with the Learner Profile, a series of dispositions for the teacher, school leader, and the student to be exemplified in school, at home, and in the community. The IB Learner Profile attributes to embrace are: inquirer, knowledgeable, thinker, communicator, principled, open-minded, risk-taker, reflective, caring, and balanced (International Baccalaureate Organization, 2009). The values and attitudes of the school community that define the culture of a school are central to shaping students as global thinkers. In a school that has a commitment to the values inherent in the IB Learner Profile, these values will be readily apparent in peer interactions, selfefficacy, and behavior in and around the campus. In addition, international-mindedness gives other cultures within the school validity and is supported by openminded teachers who model cultural competency. A summary of perspectives describing the foundations of international-mindedness from multiple research sources (Hicks \& Holden, 2007; Resnick, 2008; Roberts, 2009; Walker, 2011; ) is as follows:

- People of different backgrounds hold different views.

- Sharing and listening to different viewpoints require open-mindedness.

- Teachers model and foster a respect for cultural differences in the classroom, the community, the nation, and the world.

- Students learn to consider internationalmindedness by starting in their own community.

- International-mindedness can be demonstrated by students through personal action and community service projects.

As stated above, the International Baccalaureate is a K-12 program grounded in a philosophy aligned with the values and beliefs of international-mindedness. However, values and behaviors held by individuals and the policies and practices of organizations lead to actions that can be either unhealthy or unproductive, or healthy and productive educational environments. Therefore, values and beliefs, as well as assumptions, must be clearly defined and described and intentionally acted upon to create and sustain a healthy and productive teaching and learning environment for all students. We 
offer cultural proficiency as a conceptual frame through which individuals and organizations can examine their intentions and actions.

\section{A Framework for Cultural Proficiency}

Cultural proficiency is a conceptual framework associated with transforming education to include and promote the academic strengths of students who are the least served. Lindsey, Roberts, and CambpellJones (2005) wrote that cultural proficiency is "a way of being that allows individuals and organizations to interact effectively with people who differ from them" (p. xvi). This behavioral approach was initiated in the health care sector by Terry Cross, the executive director of the National Indian Child Welfare Association, as a model that can be applied to many constructs and environments:

A culturally competent system of care acknowledges and incorporates at all levels the importance of culture, the assessment of cross-cultural relations, vigilance towards the dynamics that result from cultural difference, the expansion of cultural knowledge, and the adoption of services to meet culturally unique needs" (Cross, Bazron, Dennis, \& Isaacs, 1989, pp. iv, v).

Cross's work has influenced other educators' work with his model of five essential elements that contribute to a system's ability to become more culturally competent. These standards of behavior have been adapted and applied to education by Lindsey et al. and are referred to as Essential Elements of Cultural Competence. These elements are:

- assessing one's own cultural knowledge,

- valuing diversity,

- dealing with conflict,

- adapting to diversity,

- $\quad$ and integrating cultural knowledge $(2005$, p. 82$)$.

With the focus on testing and accountability brought about by NCLB, school leaders and classroom teachers must look at models of cultural proficiency to improve teaching and learning and to raise the academic levels of all students. Good teaching that ignores the identity of the children in the room may not be engaging for students. Culturally proficient leaders embrace diversity and respond to it in ways that acknowledge cultural differences and help students connect to the learning. Lindsey, Terrell, Robins, and Lindsey (2010) presented nine principles of cultural proficiency:

1. Acknowledge culture as an asset-rich resource.

2. Socially just actions are the responsibility of all school personnel.

3. People have both personal identities and group identities.

4. Diversity within cultures is vast and significant.

5. A one-size-fits-all approach to culture does not work.

6. Each culture defines how the family serves to support students.

7. The school communication, expectations, and norms may not be understood by all cultures.

8. Teachers recognize their role in cross-cultural interactions.

9. Leaders incorporate culture awareness into decision and policy making.

\section{Connecting International-Mindedness and Cultural Proficiency in Public Schools}

In a school where international-mindedness and cultural proficiency purport to be a significant element, such as IB schools, a number of essential aspects of school life that expresses these mind-sets both ideologically and pragmatically may exist. Applications of these conceptual frameworks include the school mission statement, the curricular pedagogy, the assessment policies, the nature of the administration, and the role of the school principal (Roberts, 2009). The challenge facing school leaders is to know whether international-mindedness is in place and to what extent. Most importantly, a school needs to be able to understand those aspects of its life in which more should be done to develop a student's internationalmindedness (International Schools Association, 2011).

\section{International-Mindedness Themes}

As we link cultural proficiency with internationalmindedness, an appreciation of oneself, other cultures, and diverse people must be established. This foundation can build to an inquiry of potentially controversial, unjust global issues into the culturally aware school, classroom, and curriculum. Ladson-Billings (1995) 
believed a culturally relevant pedagogy would produce students who could achieve academically, demonstrate cultural competence, and both understand and critique the existing social order.

The International Baccalaureate Primary Years Programme (PYP) transdisciplinary theme "Who am I?" naturally leads students to become more culturally proficient with the perspective of internationalmindedness. Examples of lessons that describe "Who am I?" are students in kindergarten studying the family, third-graders examining the structure and purpose of their community, and fifth-grade students examining themselves in the context of their own country. In the Middle Years Programme (MYP), areas of interaction (AOI) such as "Community and Service" and "Health and Social Education" broaden and deepen the scope for internationally minded students to learn how human commonalities operate within different cultures in their own community and internationally. The study of international themes at the high school level that are present both locally and globally might include health and disease, conflict and peace, communication, poverty and hunger, clean water, and environmental sustainability.

Through the frameworks of internationalmindedness and cultural proficiency, students of all demographics and their teachers become aware of a wider world, respect and value diversity, understand how the world works, participate both locally and globally, and may be motivated to take action as engaged citizens. International understanding does not replace a sense of nationhood with something "bigger" and "better," but rather uses and builds on a sense of one's own national identity to understand and work with the national identities experienced and felt by others (Skelton, Wigford, Harper, \& Reeves, 2002). An

Table 1

Four Models of international Mindedness and Cultural Proficiency

\begin{tabular}{|c|c|c|c|c|}
\hline & $\begin{array}{l}\text { International- } \\
\text { mindedness Traits } \\
\text { (Hicks and Holden, } \\
\text { 2007) }\end{array}$ & $\begin{array}{l}\text { Cross s Cultural } \\
\text { Competence } \\
\text { Elements (Cross, } \\
\text { 1989) }\end{array}$ & $\begin{array}{l}\text { Lindsey Framework } \\
\text { for Cultural } \\
\text { Proficiency (Lindsey, } \\
\text { 2005) }\end{array}$ & $\begin{array}{c}\text { International } \\
\text { Baccalaureate } \\
\text { Philosophy (Walker, } \\
\text { 2011) }\end{array}$ \\
\hline $\begin{array}{l}\text { Foundation of the } \\
\text { program }\end{array}$ & $\begin{array}{l}\text { Know yourself and } \\
\text { then know others }\end{array}$ & Assess culture & $\begin{array}{l}\text { Culture is an asset-rich } \\
\text { resource }\end{array}$ & $\begin{array}{l}\text { Relate first to own } \\
\text { national identity, then } \\
\text { to others }\end{array}$ \\
\hline View of others & $\begin{array}{l}\text { All cultures have } \\
\text { validity }\end{array}$ & Value diversity & $\begin{array}{l}\text { People have individu- } \\
\text { al and group identi- } \\
\text { ties. Diversity within } \\
\text { groups is vast. }\end{array}$ & $\begin{array}{l}\text { The students and } \\
\text { teacher respect } \\
\text { and value diversity } \\
\text { through the Learner } \\
\text { Profile }\end{array}$ \\
\hline Teaching and learning & $\begin{array}{l}\text { Study similarities and } \\
\text { differences in cultures }\end{array}$ & $\begin{array}{l}\text { Manage the dynamics } \\
\text { of difference }\end{array}$ & $\begin{array}{l}\text { A one-size approach } \\
\text { does not work. }\end{array}$ & $\begin{array}{l}\text { The student under- } \\
\text { stands how the world } \\
\text { works through global } \\
\text { themes }\end{array}$ \\
\hline Role & $\begin{array}{l}\text { Adopt values both } \\
\text { across cultures and } \\
\text { within each culture }\end{array}$ & Adapt to diversity & $\begin{array}{l}\text { Teachers recognize } \\
\text { their role in socially- } \\
\text { just, cross-cultural } \\
\text { interactions. }\end{array}$ & $\begin{array}{l}\text { The student under- } \\
\text { stands the impact of } \\
\text { human similarities } \\
\text { and differences from } \\
\text { local to global }\end{array}$ \\
\hline Sustainability & $\begin{array}{l}\text { Is supported by teach- } \\
\text { ers and leadership }\end{array}$ & $\begin{array}{l}\text { Institutionalize cul- } \\
\text { tural knowledge }\end{array}$ & $\begin{array}{l}\text { Leaders incorporate } \\
\text { cultural awareness } \\
\text { into policy and deci- } \\
\text { sion making. }\end{array}$ & $\begin{array}{l}\text { School policy sup- } \\
\text { ports the IB mission. } \\
\text { The student is moved } \\
\text { to service learning }\end{array}$ \\
\hline $\begin{array}{l}\text { International perspec- } \\
\text { tive }\end{array}$ & $\begin{array}{l}\text { Focus on local to } \\
\text { global issues }\end{array}$ & $\begin{array}{l}\text { Makes international } \\
\text { perspective explicit }\end{array}$ & $\begin{array}{l}\text { Makes international } \\
\text { perspective explicit }\end{array}$ & $\begin{array}{l}\text { Open minded to } \\
\text { other's perspectives }\end{array}$ \\
\hline
\end{tabular}


emerging model of the complementary qualities of the philosophies of international-mindedness and cultural proficiency is presented in Table 1.

As Table 1 indicates, the conceptual frameworks of international-mindedness and cultural proficiency are grounded in the twin philosophies of International Baccalaureate and cultural competency. Teacher and school leaders who demonstrate interests and actions in developing culturally proficient and internationally minded schools will lead the way for policies and practices that embed the values and belief systems to ensure equity and access for all.

\section{Summary}

Global thinking and international-mindedness are critical pieces of twenty-first century skills and are incorporated in the new Common Core standards in an effort to reduce the achievement gap (Common Core State Standards Initiative, 2011). International Baccalaureate World Schools have been at the forefront of incorporating international-mindedness in the curriculum for more than 40 years. As education leaders enter the second decade of the 21 st-century, we see this once-elitist IB Diploma Program curriculum opening its doors to children from all strata of society in grade levels K-12 to experience and share their cultures and perspectives in an internationally minded educational environment. The population demographics in the United States are shifting and technology is more broadly used in instruction; therefore, internationalmindedness can and should be experienced in the local public school communities. To realize this goal of international-mindedness and access for all, school leaders and teachers need to understand the framework for cultural proficiency and the philosophy of international-mindedness and bring those concepts to the classroom.

\section{REFERENCES}

Alchin, N. (2008). Celebrating traditions. IB World Magazine, $52,19$.

BBC Four. (2010). Hans Rosling's 200 countries, 200 years, 4 minutes - The joy of stats [video file]. Retrieved from http://www.youtube.com/watch?v=jbkSRLYSojo

Blair, F. (1947). A school for nations (New York Herald Tribune). Retrieved from: http://alumni.ecolint.net/authors/ nations.html

Blight, G., Pulham, S., \&Torpey, P. (2011, October 20).Arab Spring, an interactive timeline: The path of protest. Retrieved from http://www.guardian.co.uk/world/interactive/2011/ mar/22/middle-east-protest-interactive-timeline

California Department of Education. (2011). Accountability progress reporting: State level API report demographics [Data file]. Retrieved from http://api.cde.ca.gov/ Acnt2011/2011GrthStAPIDC.aspx?allcds=0000000

Common Core State Standards Initiative. (2011). National Governor's Association and state education chiefs launch common state academic standards. Retrieved from http:// www.corestandards.org/articles/8-national-governorsassociation-and-state-education-chiefs-launchcommon-state-academic-standards

Cross, T., Bazron, B., Dennis, K., \& Isaacs, M. (1989). Toward a culturally competent system of care, 1 . Washington, DC: Georgetown University Child Development Center, CASSP Technical Assistance Center for Children's Mental Health.

Donald, B. (2012, February 13). Stanford study finds widening gap between rich and poor students. Stanford University News. Retrieved from http://news.stanford.edu/ news/2012/february/reardon-achievement-gap-021312. html

Hicks, D., \& Holden, C. (2007). Teaching the global dimension. New York, NY: Routledge.

Institute of Education Sciences. (2011). Achievement gaps: How Hispanic and White students in public schools perform on mathematics and reading on the National Assessment for Educational Progress (NAEP). Washington, DC: Department of Education.

International Baccalaureate Organization. (2009). The IB Learner Profile handbook. Retrieved from http://www.ibo. org/programmes/profile/

International Baccalaureate Organization. (2011). Mission statement. Retrieved from http://www.ibo.org/mission

International Baccalaureate Organization. (2012). IB at a glance. Retrieved from http://www.ibo.org/who/slidec.cfm 
International Schools Association. (2011). Consultancy services for internationalism in schools: A self-study guide. Retrieved from http://www.isaschools.org/index. php?option=com_content\&task=view\&id=86\&ltem $\mathrm{id}=62$

Kielburger, C., Kielburger, M., \& Page, S. (2010). The world needs your kid: Raising children who care and contribute. Vancouver, Canada: Greystone Books.

Ladson-Billings, G. (1995). Toward a theory of culturally relevant pedagogy. American Educational Research Journal, 32, 465-491.

Lindsey, D., Jungwirth, L., Pahl, J., \& Lindsey, R. (2009). Culturally proficient learning communities: Confronting inequities through collaborative curiosity. Thousand Oaks, CA: Corwin Press.

Lindsey, D., Terrell, R., Nuri Robins, K., \& Lindsey, R. (2010). Focus on assets: Overcoming barriers. ACSA Leadership, $39(5), 12-15$.

Lindsey, R., Roberts, L., \& CambpellJones, F. (2005). The culturally proficient school: An implementation guide for school leaders. Thousand Oaks, CA: Corwin Press.

Lindsey, R., Robins, N., \& Terrell, R. (2009). Cultural proficiency: A manual for school leaders (3rd ed.). Thousand Oaks, CA: Corwin Press.

Moll, L. C. (1992). Bilingual classroom studies and community analysis. Educational Researcher, 21(2), 20-24.

No Child Left Behind (NCLB) Act of 2001. Pub. L. No. 107-110, $\S 115$, Stat. 1425. (2002).

Paris, D. (2012). Culturally sustaining pedagogy: A needed change in stance, terminology, and practice. Educational Researcher, 41(3), 93-97.

Pierce, K. (2011, July 6). State Assembly passes Fair Education Act. Sacramento Press.

Ravitch, D. (2010). The death and life of the great American school system: How testing and choice are undermining education. Philadelphia, PA: Basic Books.

Resnik, J. (2008). The construction of the global worker through international education. In Resnik, J. (Ed.), The production of educational knowledge in the global era (pp. 147-157). Rotterdam, The Netherlands: Sense.

Roberts, B. (2009). Educating for global citizenship. Cardiff, Wales: International Baccalaureate.

Skelton, M., Wigford, A., Harper, P., \& Reeves, G. (2002). Beyond food, festivals, and flags. Educational Leadership, 60, 52.
Steele, C. M. (2010). Whistling Vivaldi and other clues to how stereotypes affect us. New York, NY: W. W. Norton.

Walker, G. (2009). Marie-Therese Maurette: Pioneer of international education, International School of Geneva. Retrieved from http://alumni.ecolint.net/authors/walker. html

Walker, G. (Ed). (2011). The changing face of international education: Challenges for the IB. Cardiff, Wales: International Baccalaureate.

Young, M. (2009). What are schools for? In: Knowledge, Values and Educational Policy. London, England: Routledge. Retrieved from http://www.shiftingthinking.org/wpcontent/uploads/2009/10/1.1-Young.pdf 
